focus on German Studies.

https://journals.uc.edu/index.php/fogs

Issue 28 (2021)

Book Review

Food, Culture and Identity in Germany's Century of War

By Heather Merle Benbow and Heather R. Perry (Eds.), Palgrave Macmillan, 2019. 280 pp. 105, $99 €$

Annelies Augustyns

Universiteit Antwerpen / Vrije Universiteit Brussel

How to Cite: Augustyns, Annelies. "Book Review: Food, Culture and Identity in Germany's Century of War". focus on German Studies 28, no. 28, 2021, pp. 218-225. DOI: 10.34314/FOGS2021.00016. 


\section{Food, Culture and Identity in Germany's Century of War}

\section{By Heather Merle Benbow and Heather R. Perry (Eds.), Palgrave Macmillan, 2019. 280 pp. $105,99 €$}

Annelies Augustyns

The twentieth century was particularly rich in crises, where fingers are often pointed at Germany. In academic research, much attention has already been paid to the war years and the role of Germany in this war-torn century from various perspectives. The collection of essays edited by Heather Merle Benbow and Heater R. Perry tries to "shed new light on old wars" (4), more exactly the so-called German-centered conflicts - First and Second World War and the Cold War - through the lens of food. Although there is a growth of food studies - based on the ideas of "father of food anthropology" Sidney Mintz and his works Sweetness and Power. The Place of Sugar in Modern History (1985) and Tasting Food, Tasting Freedom: Excursions into Eating, Culture, and the Past (1997) - examining both the social and political significance of food in history, Benbow and Perry stress that there remains a research gap in this field, more exactly concerning the "cultural, social and emotional significance of food in warfare" (2). They also emphasize that the relationship between food and the German nation has been widely overlooked in research up to now. The collection of essays is a step in trying to fill these research lacunae. Therefore, the 
editors collected eleven contributions that span different time frames and give insight into the different functions and meanings related to food.

In this context, all articles indicate that food is not just a material substance, but has wide-ranging symbolic meanings all linked to different political, personal, emotional, cultural and social understandings of food during wartime. Here, the perspective from below is also highlighted. When research on war and eventually on food has been conducted, this was usually carried out from a top-down perspective, where focus lay on political measures and repercussions, governmental policies, bureaucratic solutions, military defeat and war strategies mostly during one single event. In the present edited volume, the research perspective is inverted and expanded: the authors listen to the everyday voices and experiences of individuals - including soldiers and civilians - by relying on sources such as diaries, memoirs, letters, rumors, POW newspapers, and other more personal or lesser used accounts from varying periods of time, where food was a prevailing trope. This allows them to switch from a top-down to a bottom-up focus. This specific focus can be linked to the general increase of interest in the aspect of the everyday life. (see Lüdtke) Related to this change, the emphasis is redirected not only to typical war-time experiences at the front, but also to situations on the home front. This is the case in Perry's text Onward Kitchen Soldiers! Gender, Food and Health in Germany's Long Great War, where she zooms in on the role of the nation's housewives for cooking according to new dietary and nutrition rules. 
These should be more in line with modern ideas about health that were reshaped by nutritionists and physiologists under the harsh conditions of war and food scarcity. In this way, women played an important role in contributing to the revitalization of the nation. She indicates the cultural impacts of the food crisis, the empowerment of the German Hausfrau and the link between national health and the feeling of belonging. Jenny Sprenger-Seyffarths contribution Public Feeding in the First World War: Berlin's First Public Kitchen System relates to this question and shows the impact of war on food and nutrition and the mobilization of the national kitchen by focusing on the public kitchens and feeding programs in Berlin, Dresden and Hamburg during World War I and its relation to social descent and identity forming.

This study gives new evidence of how food, indeed, did not just provide sustenance, but became politicized. It played a crucial role in power relations and wartime propaganda and was always imbued with ambiguity. Encounters with the other could, for instance, be complicated or facilitated by food, as has been demonstrated in Benbow's text Food, Drink and Hunger for World War I German Soldiers. She analyzes soldier memoirs and letters where food, drink and hunger were dominant experiences and illustrates the role of food in different kind of interactions: among soldiers, between soldiers and their family and between soldiers and civilians. In these different relations, food was either able to shape relations and constitute a consoling and comforting element or disrupt them and threaten comradely 
bonds. It was either an act of caring, hospitality and humanity or a matter of social division and punishment. This ambiguous role comes to the fore in all contributions and can also be related to the question of identity-formation. This latter issue is treated with a specific focus in the accounts of Christine Rinne, Christine Fojtik, Laura J. Hilton and John Gillespie.

Even though the popular image of Germany as a nation of farmers and as a completely self-sustaining nation was a myth, the postwar situation, the loss of eastern (farm)lands and food crisis challenged Germany's self-understanding even more, leading to considerations and tensions as to how it presented itself: as industrial or, as it used to, as an agricultural state. These issues are treated in Fojtiks contribution The Productive Heimat: Territorial Loss and Rurality in German Identity at the Stunde Null. She also links this question with Germany's division by Allies and continued difficulties with food in American and British controlled zones, which is further examined in Kaete O'Connell's text The Taste of Defeat: Food, Peace and Power in US-Occupied Germany. She shows how food was being used as weapon of war and/or peace in civil-military relations and negotiations. In Postwar Food Rumors: Security, Victimhood and Fear, Hilton not only indicates how food and identity are intertwined, but highlights how food clearly played a role in political discourse, where it was central to conflicts and debates. Food was even misused and reinterpreted in postwar German rhetoric. Basing her research on rumors revolving around food in post-war Germany, she demonstrates how Germans inverted the perspective of 
them as perpetrators and instead represented themselves as victims of the Allies, who were depicted as starving and punishing the German population. It was this image that impacted upon the collective memory of Germany. Gillespie also makes clear how food - or more exactly beer - was a core element in the postwar discourse of East Germany and how it even became a central element of its postwar identity. The socialist German Democratic Republic (GDR), for example, promoted beer as a drink of the socialist worker and thereby differentiated itself from the so-called decadence of capitalist West-Germany and the imported culture from America, even though the GDR itself struggled to maintain basic quality standards of beer. The false narratives produced by the GDR disguised reality and deflected attention in favor of the state itself. Not only beer, but also coffee was a central element in its discourse for making itself more attractive and even provided an opportunity for making (transnational) alliances with another socialist state, Vietnam, during the Cold War as is shown in Andrew Kloiber.

Given the wide range of topics, Benbow and Perry promote their volume as providing “[t]he occasion to examine the multi-valency of Germany's food experiences across the twentieth century within the contextual pressures and changing dynamics of modern warfare" (3). However, this statement raises questions. Although the articles stretch their focus from the beginning of the twentieth century with the First World War to the Second World War and the post-war situation of Germany ending with the Cold war, the emphasis 
lies on the Great War and the post-war situation. The Second World War and the period of the Third Reich are merely treated as marginal, even though they mark important turning points in German history. There are three articles dealing with the First World War - the ones by Perry, Benbow and Sprenger-Seyffarth - the ones of Fojtik, Hilton and O'Connell grapple with the post-war situation, and the Cold war is being handled in the articles by Gillespie and Kloiber. In Fojtik and Hilton there are minor hints about the situation in the Third Reich, but they are not further elaborated upon. The contribution by Helene J. Sinnreich revolves around Nazi Policy, its racial based food approach and the ensuing consequences in the ghettos of occupied Eastern Europe. The article illustrates in a fascinating way how the (Eastern) Jews in the Ghettos were impacted by the food laws, how food used to be an important element in convincing Jews to board the deportation trains, and which tactics - varying among others between selling possessions, begging, smuggling, theft, prostitution - helped them to survive, but I wonder why the situation of Eastern Europe and the Eastern Jews deserve specific attention in a volume dedicated originally to the German question. Even though there were no ghettos in Germany - Kwiet (1988) speaks about a "ghettoization without ghettos" - it would have been compelling to direct the focus to the situation of the Jews in German towns and cities or the overall food situation in Germany during the Third Reich and the ensuing Second World War. Dispossession and Food deprivations were namely not merely bound to Jewish ghettos in occupied Europe. 
Regarding the Second World War, Rinne depicts the significance of food in the POW newspapers Der Zaungast and POW-Oase from, respectively Camp Aliceville and Fort McClellan in Alabama. The transnational perspective is promising and shows how food and social rituals were used to differentiate themselves from Americans, and how they are tied to nostalgia and a longing for the distant home. An investigation of personal documents from soldiers at the front or citizens at the home front during the Second World War in Germany would have been an interesting addition. When Benbow, for instance, investigates how World War I German soldiers were bound or devised by food, it could have been interesting to compare this situation with the one of World War II, where racial issues were played out. Even though there remain some lacunae, the volume offers a wide range of insights, both on a national and transnational level, illustrating how food in the desperate conditions of war and its aftermath is more than simple nourishment and requirement of life. It was a carrier of (emotional) meaning and important in relationships with others, as it was ambiguously politicized as both weapon of war and tool of peace. In this way, the volume offers an enlightening and new perspective on Germany's twentieth century of war and definitely contributes to the disciplines of culture and food studies as well as to war and social studies. 